\title{
Baculoviral IAP Repeat-Containing Protein
} 1

National Cancer Institute

\section{Source}

National Cancer Institute. Baculoviral IAP Repeat-Containing Protein 1. NCI Thesaurus.

Code C20928.

Baculoviral IAP repeat-containing protein 1 (1403 aa, $160 \mathrm{kDa})$ is encoded by the human NAIP gene. This protein is involved in the modulation of both apoptosis and neuronal development. 